\title{
PENGARUH PENDEKATAN OPEN-ENDED DAN PENDEKATAN KONTEKSTUAL TERHADAP KEMAMPUAN PEMECAHAN MASALAH DAN SIKAP SISWA TERHADAP MATEMATIKA
}

\author{
Raden Heri Setiawan ${ }^{1)}$, Idris Harta ${ }^{2)}$ \\ Prodi Pendidikan Matematika ${ }^{1)}$, Universitas Negeri Yogyakarta ${ }^{2)}$ \\ radenherrysetyawan@gmail.com ${ }^{1)}$, idrissenaharta@gmail.com ${ }^{2)}$
}

\begin{abstract}
Abstrak
Penelitian ini bertujuan untuk mendeskripsikan keefektifan pembelajaran dengan pendekatan open-ended dan kontekstual pada aspek kemampuan pemecahan masalah dan sikap siswa terhadap matematika dan membandingkan keefektifan kedua pendekatan tersebut pada aspek kemampuan pemecahan masalah dan sikap siswa terhadap matematika. Penelitian ini adalah penelitian eksperimen semu. Populasi penelitian mencakup seluruh siswa kelas VIII SMP Negeri 6 Yogyakarta yang terdiri dari tujuh kelas. Dari populasi yang ada diambil dua kelas yaitu kelas VIII E dan VIII F sebagai sampel penelitian. Instrumen yang digunakan untuk mengumpulkan data adalah tes kemampuan pemecahan masalah dan angket sikap siswa terhadap matematika. Untuk menguji keefektifan pembelajaran matematika dengan pendekatan open-ended dan pendekatan kontekstual, digunakan analisis one sample t-test. Untuk membandingkan keefektifan pendekatan open-ended dan pendekatan kontekstual, data dianalisis dengan menggunakan uji $\mathrm{T}^{2}$ Hotelling, dan uji t dengan kriteria Bonferroni untuk menentukan pendekatan pembelajaran manakah yang lebih efektif. Hasil penelitian menunjukkan bahwa: (1) pembelajaran matematika dengan pendekatan open-ended dan pendekatan kontekstual efektif pada aspek kemampuan pemecahan masalah dan sikap siswa terhadap matematika, (2) pendekatan open-ended lebih efektif dibandingkan pendekatan kontekstual pada aspek kemampuan pemecahan masalah, (3) pendekatan open-ended tidak lebih efektif dibandingkan pendekatan kontekstual pada aspek sikap siswa terhadap matematika.
\end{abstract}

Kata Kunci: pendekatan open-ended, pendekatan kontekstual, kemampuan pemecahan masalah dan sikap siswa terhadap matematika.

\section{THE EFFECTS OF THE OPEN-ENDED APPROACH AND CONTEXTUAL APPROACH ON THE PROBLEM SOLVING ABILITY AND STUDENT'S ATTITUDE TOWARDS MATHEMATICS}

\begin{abstract}
This study aims to describe the effectiveness of learning through open-ended and contextual approaches on the problem solving ability and students' attitude towards mathematics and to compare the effectiveness of both approaches on the problem solving ability and students' attitude towards mathematics. This study was a quasi-experimental study. The research population comprised all year8 students' of SMP Negeri 6 Yogyakarta, consisting of seven classes. From the population, two classes, i.e. class VIII E and class VIII F, were established as the research sample. The data collecting instruments consisted of a problem solving ability test and questionnaires for students' attitude towards mathematics. To test the effectiveness of the mathematics learning through the open-ended approach and the contextual approach, the one sample t-test was carried out. To compare the effectiveness of the open-ended approach and the contextual approach, the data were analyzed using the T-Hotelling test, and the t-test with Bonferroni criteria to find out which of the two approaches was more effective. The results of the study show that: (1) mathematics learning through the openended approach and the contextual approach is effective on the problem solving ability and students' attitude towards mathematics; (2) the open-ended approach is more effective than the contextual approach for problem solving ability; (3) the open-ended approach is not more effective than the contextual approach for students' attitude towards mathematics.
\end{abstract}

Keyword: open-ended approach, contextual approach, problem solving ability and students' attitude towards mathematics. 


\section{PENDAHULUAN}

Berdasarkan standar isi, tujuan umum pendidikan matematika pada jenjang pendidikan sekolah menengah pertama yaitu memberi tekanan pada penataan nalar, kemampuan pemecahan masalah, mengkomunikasikan ide-ide dan pembentukan sikap. Salah satu aspek penting dalam pembelajaran matematika adalah aspek pemecahan masalah. Pentingnya kemampuan pemecahan masalah matematika sebagaima dapat dilihat pada perannya dalam pembelajaran. Stanic \& Kilpatrick seperti dikutip McIntosh \& Jarret (2000, p.8) membagi peran pemecahan masalah sebagai konteks menjadi beberapa hal: (1) untuk pembenaran pengajaran matematika, (2) untuk menarik minat siswa akan nilai matematika, dengan isi yang berkaitan dengan masalah kehidupan nyata, (3) untuk memotivasi siswa, membangkitkan perhatian siswa pada topik atau prosedur khusus dalam matematika dengan menyediakan kegunaan kontekstualnya (dalam kehidupan nyata), (4) untuk rekreasi, sebagai suatu aktivitas menyenangkan yang memecah suasana belajar rutin, (5) sebagai latihan, penguatan keterampilan dan konsep yang telah diajarkan secara langsung.

Menurut Pehkonen (1997, p.64) alasan pentingnya pemecahan masalah diberikan karena pemecahan masalah: (1) dapat mengembangkan keterampilan kognitif, (2) dapat meningkatkan kreativitas, (3) merupakan bagian dari proses aplikasi matematika, (4) dapat memotivasi siswa untuk belajar matematika. Menurut Wilson, Fernandez, \& Hadaway (1993) bahwa pemecahan masalah memiliki peranan penting yang istimewa dalam matematika. Tujuan utama dalam belajar dan mengajar matematika adalah untuk mengembangkan kemampuan dalam memecahkan berbagai macam masalah matematika yang kompleks. Oleh sebab itu Cockcroft (Taplin, 1998) menganjurkan pemecahan masalah sebagai sarana mengembangkan pemikiran matematika menjadi alat untuk hidup sehari-hari. Lebih lanjut dikatakan bahwa kemampuan pemecahan masalah terletak di jantung matematika.

Di sisi lain beberapa hasil penelitian memperlihatkan bahwa kemampuan pemecahan masalah matematis siswa di sekolah menengah secara umum belum mencapai hasil yang memuaskan. Salah satunya yaitu penelitian yang dilakukan Suryadi dalam Suherman, Turmudi, Suryadi, dkk. (2003, p.89) menemukan bahwa pemecahan masalah matematika merupakan salah satu kegiatan matematika yang dianggap penting baik oleh para guru maupun siswa di semua tingkatan mulai dari SD sampai SMU, akan tetapi hal tersebut masih dianggap sebagai bagian yang paling sulit dalam matematika baik bagi siswa dalam mempelajarinya maupun bagi guru dalam mengajarkannya.

Rendahnya kemampuan pemecahan masalah matematika di Indonesia dapat dilihat dari hasil kompetisi matematika tingkat internasional Programme for International Student Assesment (PISA) yang diadakan 3 tahun sekali di bidang membaca, matematika, dan sains. Hasil tes menunjukkan kemampuan siswa Indonesia berada di bawah rata-rata skor internasional. Berdasarkan Hasil PISA 2009 kualitas pembelajaran matematika Indonesia berada pada peringkat 68 dari 74 negara (Wikipedia, 2012). Demikian pula dalam tes Trends in International Mathematics and Science Study (TIMSS) yang diadakan 4 tahun sekali, di bidang matematika dan sains. Hasil tes juga menunjukkan kemampuan siswa Indonesia berada di bawah rata-rata skor internasional. Berdasarkan Hasil TIMSS 2011 kualitas pembelajaran matematika Indonesia berada pada peringkat 38 dari 42 negara (Kompasiana, 2012).

Berdasarkan hasil studi TIMSS dan PISA di bidang matematika, siswa Indonesia belum mampu menyelesaikan soal yang menuntut kemampuan berpikir tingkat tinggi seperti kemampuan pemecahan masalah. Seperti dinyatakan oleh Strategic Review (2011) berdasarkan PISA yang diwakili oleh siswa berumur 15 tahun, setengah dari siswa Indonesia hanya mencapai skor di bawah level 1 dalam matematika (pada skala 6-level), sementara tidak ada yang mencapai level 5 atau 6, di mana level tersebut mengukur kreativitas, pemecahan masalah dan penalaran yang kompleks. Berikut ini beberapa gambaran kelemahan siswa Indonesia dalam menyelesaikan soal-soal Matematika dari PISA dan TIMSS yang disadur dari laporan hasil survei PISA tahun 2000 dan TIMSS tahun 2003 terbitan tahun 2006 oleh Puspendik Balitbang Depdiknas (Wardhani \& Rumiati, 2011, pp.5156)

Siswa kita lemah dalam soal aplikasi yang memuat suatu cerita, meskipun soalnya sederhana. Sebagai ilustrasi disajikan soal TIMSS 2003 sebagai berikut 
Buku Gito dua kali lebih banyak dari buku Budi. Buku hari enam buah lebih banyak dari buku Budi. Jika Budi memiliki $\mathrm{x}$ buah buku, berapa buku yang dimiliki ketiga anak tersebut?

Laporan hasil studi menyebutkan bahwa ternyata hanya $20 \%$ saja dari siswa kita yang menjawab dengan benar, sementara $80 \%$ menjawab salah. Siswa kita lemah dalam mengerjakan soal-soal yang menuntut kemampuan pemecahan masalah, berargumentasi dan berkomunikasi. Sebagai ilustrasi disajikan soal TIMSS 2003 berikut ini.

Total Biaya Perjalanan untuk semua siswa harus sebesar 500 zeds atau kurang. Semuanya ada 30 siswa. Di bawah ini adalah biaya kunjungan untuk masing-masing kota

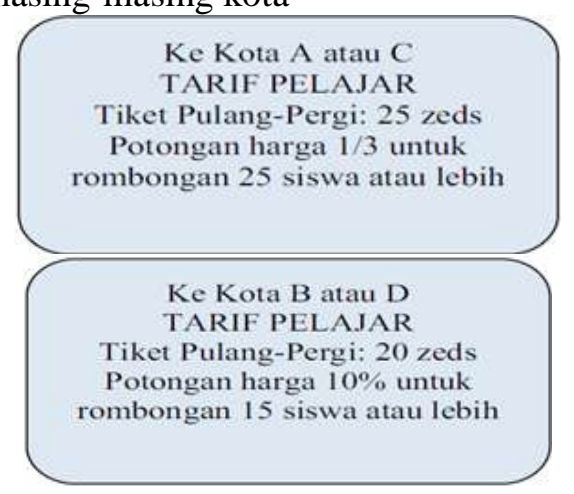

Kota manakah yang mereka unjungi? Tuliskan langkah-langkah penyelesaiannya.

Laporan hasil studi menyebutkan bahwa hanya $3,0 \%$ saja dari siswa kita yang menjawab benar, sebanyak 4,6\% siswa men-jawab benar sebagian, sementara $92,4 \%$ siswa menjawab salah.

Siswa kita lemah dalam menyele-saikan soal terkait konten geometri, khususnya dalam pemahaman ruang dan bentuk. Sebagai ilustrasi disajikan soal PISA 2000 sebagai berikut.

Sebuah kubus besar dicat. Ku-

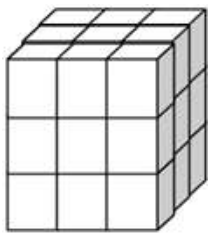

bus besar tersebut kemudian dipotong menjadi tiga bagian dari tiga arah yang berbeda dan menghasilkan banyak kubus kecil seperti gambar disamping. Berapa banyaknya kubus kecil yang dihasilkan?

Menurut laporan, hanya $33,4 \%$ siswa yang menjawab benar. Rendahnya kemampuan pemecahan masalah matematis siswa mengindikasikan ada sesuatu yang belum optimal dalam pembelajaran matematika di sekolah. Menurut hasil survey IMSTEP-JICA di Kota Bandung (Herman, 2007, p.48) bahwa salah satu penyebab rendahnya kualitas pemahaman matematika siswa di SD dan SMP adalah karena dalam proses pembelajaran matematika, guru umumnya terlalu berkonsentrasi pada latihan menyelesaikan soal yang lebih bersifat prosedural dan mekanistis daripada pengertian.

Selain kemampuan pemecahan masalah, ada aspek lain yang tidak kalah pentingnya dalam mempengaruhi hasil belajar siswa yaitu sikap terhadap matematika. Menurut Norjoharuddeen (Shadiq, 2008, p.1) bahwa terdapat dua faktor yang dapat mempengaruhi proses pembelajaran matematika pada diri setiap siswa, yaitu: (1) faktor kognitif dan (2) faktor nonkognitif (afektif). Faktor kognitif berkaitan dengan kemampuan otak dalam berpikir. Contohnya kemampuan bernalar. Faktor non-kognitif (afektif) berkaitan dengan kemampuan di luar kemampuan otak dalam berpikir. contohnya perasaan senang atau tidak senang mempelajari matematika. Hal senada juga dilontarkan oleh Wardhani (2004, p.15) bahwa komponen afektif juga ikut menentukan keberhasilan belajar matematika siswa. Lebih lanjut dikatakan ada beberapa komponen afektif, salah satunya adalah sikap. Sikap merupakan suatu karakter seseorang yang menggambarkan perasaan positif dan negatif mereka terhadap objek, situasi, institusi, seseorang atau suatu ide (Nitko \& Brookhart, 2007, p.451).

Menurut Sanjaya (2011, p.286) proses pendidikan bukan hanya membentuk kecerdasan dan/atau memberikan keterampilan tertentu saja akan tetapi juga membentuk dan mengembangkan sikap agar anak berperilaku sesuai dengan norma-norma yang berlaku di masyarakat. Menurut Neale (1969, p.631) sikap memainkan peranan yang sangat penting dalam belajar matematika. Pertama, suatu sikap dianggap sebagai tujuan dalam pembel-ajaran matematika. Kedua, sikap positif terhadap matematika menyebabkan siswa mau belajar matematika. Sejalan dengan hal tersebut, kurikulum 2006 telah menempatkan pembentukan sikap positif sebagai salahsatu tujuan pembelajaran matematika.

Walaupun demikian, fakta di lapangan menunjukkan bahwa sampai saat ini sebagian besar siswa masih bersikap negatif terhadap matematika. Menurut Boediono (2004, p.3) statistika merupakan pelajaran yang ditakuti, dijauhi, dan dianggap sulit bagi pelajar maupun mahasiswa sebagaimana mereka memandang mate- 
matika, bahkan masyarakat telah menjadikan statistika dan matematika sebagai momok dalam kehidupan sehari-hari. Hal senada juga diungkapkan oleh Rusgianto (2006, p.64) bahwa kenyataan untuk semua tingkatan sekolah, banyak siswa yang bersikap negatif terhadap matematika, siswa menganggap matematika sebagai bidang studi yang sulit dipelajari, mereka takut terhadap matematika. Tentu saja pandangan atau sikap negatif siswa terhadap matematika berpengaruh terhadap cara-cara siswa dalam mempelajari matematika. Oleh karena itu diduga bahwa sikap negatif siswa terhadap matematika, merupakan salah satu indikator penyebab rendahnya hasil belajar matematika siswa.

Dalam pembelajaran matematika kontemporer, dikenal ada beberapa pendekatan pembelajaran yang telah terbukti mampu meningkatkan kemampuan pemecahan masalah lebih baik daripada pendekatan konvensional. Dua diantaranya yaitu Pendekatan open-ended dan Pendekatan kontekstual. Kedua pendekatan pembelajaran ini akan digunakan dalam penelitian untuk meminimalisir permasalahan di atas. Kedua pendekatan pembelajaran ini dipilih karena sejalan dengan program pemerintah dalam upaya meningkatkan mutu pendidikan matematika yang tertuang dalam Permendiknas No 22 tahun 2006. Selain itu, hal ini juga didasarkan oleh pandangan para ahli berkaitan dengan kedua pendekatan tersebut.

Berkaitan dengan pendekatan open-ended, Nohda (2000) berpendapat bahwa pendekatan open-ended sangat penting bagi setiap siswa untuk memiliki kebebasan dalam meningkatkan kemampuan pemecahan masalah sesuai dengan tingkat kemampuan dan minat mereka. Pendapat lain Yamazaki (Hino, 2007, p.507) menyatakan pengajaran matema-tika dengan menggunakan soal-soal terbuka adalah salah satu metode representatif untuk meningkatkan kemampuan pemecahan masalah siswa di Jepang. Berdasarkan hasil penelitian Inprasitha (2006) melalui proyek lesson study di Thailand yang melibatkan 1200 siswa dari tujuh sekolah menengah yang diajarkan dengan pendekatan terbuka. Penelitian ini menghasilkan kesimpulan bahwa sebagian besar siswa dari sekolah-sekolah tersebut mempunyai sikap positif terhadap pendekatan terbuka.

Di pihak lain Berns \& Ericson (2001, p.2) berpendapat bahwa pembelajaran kontekstual bertujuan untuk meningkatkan kemampuan berpikir tingkat tinggi seperti kemampuan pemecahan masalah, kemampuan berpikir kritis dan dalam membuat keputusan. Selain dapat meningkatkan kemampuan pemecahan masalah pendekatan kontekstual juga dapat meningkatkan sikap positif siswa. Hal ini sesuai dengan pendapat Owens (Sulianto, 2011) bahwa pengajaran konteksual secara praktis menjanjikan peningkatan minat, keter-tarikan belajar siswa dari berbagai latar belakang serta meningkatkan partisipasi siswa dengan mendorong secara aktif dalam mem-berikan kesempatan kepada mereka untuk mengkoneksikan dan mengaplikasikan penge-tahuan yang telah mereka peroleh.

Pendekatan open-ended adalah suatu metode penggunaan soal-soal open-ended di dalam kelas untuk membangkitkan kegiatan diskusi (Pehkonen, 1997, p.64). Soal open-ended (masalah terbuka) adalah masalah yang diformulasikan memiliki banyak metode penyelesaian dan jawaban benar lebih dari satu (Shimada, 1997, p.1). Jadi pendekatan open-ended merupakan suatu pendekatan pembelajaran yang memberikan kesempatan kepada siswa untuk menyelesaikan masalah dengan berbagai cara dan jawaban benar lebih dari satu, kemudian didiskusikan untuk saling membandingkan hasil pekerjaan.

Menurut Hino (2007, p.508) masalah terbuka (open-ended problem) adalah suatu masalah yang diformulasikan sedemikian sehingga memiliki beberapa jawaban yang benar. Selanjutnya Pehkonen (1999, p.57) menjelaskan bahwa suatu masalah dikatakan terbuka, apabila starting point atau tujuan masalah tersebut tidak secara jelas diberikan. Lebih lanjut dia mengatakan bahwa masalah open-ended dapat diklasifikasikan menjadi beberapa macam, yaitu: (1) investigasi (di mana starting point diberikan), (2) problem posing (atau problem finding atau problem formulating), (3) real-life situation (masalah yang mana akar permasalahannya berasal dari kehidupan sehari-hari), (4) projects (yaitu entitas penelitian yang lebih besar, yang membutuhkan kerja mandiri), (5) problem fields (atau problem sequences atau problem domains, suatu masalah yang dihubungkan dengan sekumpulan masalah kontekstual), (6) problems without a question, dan (7) problem variations ("what-if"-method).

Menurut Nohda (2000) ide dari pendekatan open-ended digambarkan sebagai suatu metode pengajaran di mana aktivitas interaksi antara matematika dan siswa terbuka dalam berbagai macam pendekatan pemecahan masalah. Makna aktivitas interaksi antara ide-ide matematis dan siswa dikatakan terbuka dalam berbagai macam pendekatan pemecahan masalah dapat dijelaskan 
melalui tiga aspek yaitu: (1) aktivitas siswa dikembangkan melalui pendekatan terbuka, (2) suatu masalah yang digunakan dalam pendekatan open-ended melibatkan ide-ide matematis, (3) pendekatan open-ended harus selaras dengan aktivitas inter-aksi antara (1) dan (2).

Berkaitan dengan pendapat Nohda tersebut, Sullivan, Bourke, \& Scott (1995, p.485) menjelaskan: Pertama, ada keterbukaan dalam kegiatan siswa. Hal utama di sini yaitu pertanyaan-pertanyaan tersebut ditentukan sendiri oleh siswa. Hal ini memberikan kontribusi yang besar untuk memotivasi siswa dalam memecahkan masalah. Kedua, ada keterbukaan dalam konten matematika. Tidak hanya potensi matematika yang dimunculkan, akan tetapi kemungkinan adanya generalisasi dan diversifikasi masalah. Ketiga, adanya keterbukaan interaksi antara siswa dan konten matematika. Dalam hal ini Nohda mempertentangkannya dengan pengajaran konvensional di mana guru merencanakan pelajaran dan pendekatan terlebih dahulu dengan tipe ini, yaitu soal-soal siswa dan jawabannya telah ditentukan oleh guru dan kemudian digunakan oleh guru sebagai dasar dari tugas-tugas selanjutnya. Dia juga menyatakan bahwa pendekatan ini melayani berbagai kemampuan dalam kelas.

Hal serupa juga dijelaskan oleh Suherman, Turmudi, Suryadi, dkk. (2003, pp.125-127) bahwa aktivitas siswa harus terbuka yaitu kegiatan pembelajaran harus mengakomodasi kesempatan siswa untuk melakukan segala sesuatu secara bebas sesuai dengan kehendak mereka. Lebih lanjut dijelaskan bahwa aktivitas siswa dan ide-ide matematis dikatakan selaras, jika kebutuhan dan berpikir matematis siswa terperhatikan guru melalui kegiatan-kegiatan matematika yang bermanfaat untuk menjawab permasalahan lainnya. Dengan kata lain, ketika siswa melakukan kegiatan matematika untuk memecahkan permasalahan yang diberikan, dengan sendirinya akan mendorong potensi mereka untuk melakukan kegiatan matematika pada tingkatan berpikir yang lebih tinggi. Dengan demikian, guru tidak perlu mengarahkan agar siswa memecahkan permasalahan dengan cara atau pola yang sudah ditentukan, sebab akan menghambat kebebasan berpikir siswa untuk menemukan cara baru menyelesaikan permasalahan. Jadi secara ringkas pembelajaran dengan pendekatan open-ended tidak hanya memberikan masalah-masalah terbuka kepada siswa untuk diselesaikan akan tetapi juga harus menjamin keterbukaan aktivitas siswa dalam proses pembelajarannya.

Pembelajaran dengan pendekatan kontekstual (Contextual Teaching and Learning) menurut Berns dan Ericson (2001, p.2) adalah suatu konsep pembelajaran yang dapat membantu guru menghubungkan materi pelajaran dengan situasi dunia nyata dan memotivasi siswa untuk membuat koneksi antara pengetahuan dan penerapannya pada kehidupan sehari-hari dalam peran mereka sebagai anggota keluarga, warga negara dan pekerja, sehingga mendorong motivasi mereka untuk bekerja keras dalam menerapkan hasil bel-ajarnya.

Menurut Johnson (2002, p.vii) CTL adalah suatu sistem pembelajaran yang berdasarkan pada filosofi dimana siswa belajar ketika mereka menemukan makna dalam materi akademik dan mereka menemukan makna di sekolah sehingga mereka dapat menghubungkan informasi baru tersebut dengan pengetahuan dan pengalaman sebelumnya.

Menurut Johnson (2007, p.65-66), sistem CTL mencakup delapan komponen berikut ini: (1) Membuat keterkaitan-keterkaitan yang bermakna; (2) Melakukan pekerjaan yang berarti; (3) Melakukan pembelajaran yang diatur sendiri; (4) Bekerja sama; (5) Berpikir kritis dan kreatif; (6) Membantu individu untuk tumbuh dan berkembang; (7) Mencapai standar yang tinggi; dan (8) Menggunakan penilaian autentik.

Kedelapan komponen CTL tersebut juga sejalan dengan tujuh komponen CTL yang ada dalam KTSP yaitu: konstruktivisme (Constructivism), bertanya (Questioning), menemukan (Inquiry), komunitas belajar (Learning Community), pemodelan (Modelling), refleksi (Reflection), dan penilaian sebenarnya (Authentic Assessment) (Masnur Muslich, 2007, p.43).

Menurut Mayer \& Wittrock (2006, p.288) masalah matematika dapat diklasifikasikan menjadi masalah rutin (routine problem) dan masalah tidak rutin (non-routine problem). Masalah rutin adalah suatu masalah yang mana seorang pemecah masalah tersebut sudah mempunyai prosedur penyelesaian yang siap pakai. Masalah tidak rutin adalah suatu masalah yang mana seorang pemecah masalah tidak mempunyai prosedur penyelesaian yang siap pakai sebelumnya.

Menurut Schoenfeld (1985, p.74) bahwa sulitnya dalam mendefinisikan istilah masalah karena dalam pemecahan masalah merupakan hal yang relatif bagi setiap orang. Suatu tugas yang sama yang diberikan memerlukan usaha yang keras oleh beberapa siswa akan tetapi bisa 
menjadi soal latihan rutin bagi siswa yang lain. Oleh sebab itu Krulick dan Rudnick (Brumbaught, Rock, Brumbaught, et al., 2003, p.216) memberikan empat hal yang esensial untuk menentukan apakah suatu soal dapat dikategorikan masalah yaitu: (1) soal tersebut menarik untuk dipelajari; (2) soal tersebut menantang; (3) siswa tersebut tertantang untuk menyelesaikannya; (4) terdorong oleh sikap positif untuk memecahkan masalah. Pendapat lain menurut Schoen and Oehmke (Quinones, 1996) bahwa suatu soal akan menjadi masalah bagi seseorang jika: (1) soal membutuhkan solusi dalam kondisi tertentu, (2) orang memahami soal namun tidak melihat strategi langsung untuk mendapatkan jawaban, (3) orang tersebut termotivasi untuk mencari solusi.

Terdapat banyak interpretasi tentang pemecahan masalah dalam matematika. Di antaranya pendapat Polya (1981, p.117) mengartikan pemecahan masalah sebagai suatu usaha mencari jalan keluar dari suatu kesulitan guna mencapai suatu tujuan yang tidak begitu segera dapat dicapai.

Pendapat lain dikemukakan oleh Gagne dalam Orton (2006, p.84) pemecahan masalah sebagai bentuk belajar yang paling tinggi tingkatannya didefinisikan sebagai suatu proses yang mana pembelajar menemukan suatu kombinasi dari aturan yang sebelumnya dipelajari dimana dapat digunakan untuk mencapai jawaban dari cerita situasi masalah. Menurut Haylock (2007, pp.145-146) pemecahan masalah yaitu ketika seorang individu menggunakan pengetahuan dan penalaran matematikanya untuk mengatasi kesenjangan antara kodrat dan tujuan.

Sternberg dan Ben-Zeev (1996, p.31) menyatakan, pemecahan masalah adalah suatu proses kognitif yang membuka peluang pemecah masalah untuk bergerak dari suatu keadaan yang tidak diketahui bagaimana pemecahannya ke suatu keadaan tetapi tidak mengetahui bagaimana cara memecahkannya. Jadi, ada kendali untuk berproses mencapai tujuan. Dahar (1989, p.138), bahwa pemecahan masalah merupakan suatu kegiatan manusia yang menggabungkan konsep-konsep dan aturan-aturan yang telah diperoleh sebelumnya, dan tidak sebagai suatu keterampilan generik.

Stanic dan kilpatrick (McIntosh \& Jarret, 2000, p.8) mengidentifikasi tiga peran utama pemecahan masalah dalam pembelajaran matematika yaitu sebagai konteks (problem solving as context), sebagai keterampilan (problem solving as skill), dan sebagai seni dari matematika (problem solving as art). Ketiga peran utama pemecahan masalah tersebut akan di jelaskan sebagai berikut:

Ketika pemecahan masalah digunakan sebagai konteks untuk matematika, penekanannya adalah untuk menemukan soal-soal yang menarik atau masalah yang membantu menjelaskan konsep atau prosedur matematika. Tujuan utama dari proses ini adalah siswa memahami konsep matematika dan bukanlah pemecahan masalah itu sendiri. Dengan menyediakan konteks pemecahan masalah, tujuan guru adalah: (1) untuk menciptakan kesempatan bagi siswa untuk membuat penemuan tentang konsep menggunakan media yang familiar dan diinginkan (motivasi), (2) untuk membantu membuat suatu konsep menjadi lebih konkret (melalui praktek), (3) untuk menawarkan alasan untuk belajar matematika (pembenaran).

Pemecahan masalah sebagai keterampilan yaitu mengajarkan keterampilan pemecahan masalah sebagai topik yang terpisah dari kurikulum maksudnya bukan sarana untuk mengembangkan pemahaman konseptual dan ketermpilan dasar melainkan mengajarkan seperangkat aturan umum untuk memecahkan masalah seperti menggambar, bekerja mundur, trial and error, atau membuat daftar-praktik.

Pemecahan masalah sebagai seni, dalam buku klasiknya Polya (1985) yang berjudul "How to Solve It" memperkenalkan gagasan bahwa pemecahan masalah dapat diajarkan sebagai seni praktis, seperti bermain piano atau berenang. Polya melihat pemecahan masalah sebagai tindakan penemuan dan memperkenalkan istilah "heuristik modern" (seni penyelidikan dan penemuan) yaitu menggambarkan kemampuan yang dibutuhkan untuk mencapai keberhasilan dalam menyelidiki masalah baru. Dia mendorong menyajikan matematika bukan sebagai seperangkat penyelesaian fakta dan aturan, tetapi sebagai ilmu eksperimental dan induktif. Tujuan mengajarkan pemecahan masalah sebagai seni adalah untuk mengembangkan kemampuan siswa, menjadi terampil, menjadi pemecah masalah yang antusias, dan untuk menjadi pemikir independen yang mampu menangani secara terbuka masalah yang tidak jelas

Ada beberapa langkah pemecahan masalah yang dikemukakan oleh para ahli, yang kemudian digunakan untuk mengukur kemampuan pemecahan masalah matematika. Salah satunya yang banyak dirujuk yaitu langkah-langkah pemecahan masalah menurut Polya. Polya (1985, pp.5-6) menguraikan proses yang dapat dilaku- 
kan pada setiap langkah pemecahan masalah. Proses tersebut terangkum dalam empat langkah berikut: (1) memahami masalah (understanding the problem). (2) merencanakan penyelesaian (devising a plan). (3) melaksanakan rencana (carrying out the plan). (4) memeriksa proses dan hasil (looking back).

Nitko \& Brookhart (2007, p.451) mendefinisikan sikap sebagai suatu karakter seseorang yang menggambarkan perasaan positif dan negatif mereka terhadap objek, situasi, institusi, seseorang atau suatu ide. Menurut Ebel dan Frisbie (1986, p.320) menyatakan bahwa sikap adalah organisasi keyakinan menyangkut objek atau situasi yang mempengaruhi seseorang untuk memberikan respon dalam dengan cara istimewa yang relatif tetap.

Menurut Allen, Guy, \& Edley (Azwar, 2011, p.5) mendefinisikan sikap sebagai suatu pola perilaku, tendensi atau kesiapan antisipatif, predisposisi untuk menyesuaikan diri dalam situasi sosial, atau secara sederhana sikap adalah respon terhadap stimuli sosial yang telah terkondisikan. Pendapat lain dinyatakan oleh Eagly dan Chaiken (1993, p.1) bahwa sikap adalah kecenderungan psikologis yang diekspresikan dengan mengevaluasi suatu entitas tertentu dengan beberapa tingkat kebaikan hati atau tidak. Sanjaya (2007, p.276) mendefinisikan sikap sebagai kecenderungan seseorang untuk menerima atau menolak suatu objek berdasarkan nilai yang dianggapnya baik atau tidak baik.

Proses pembentukan sikap menurut Sanjaya (2007, p.275) ada dua cara yaitu pola pembiasaan dan modeling. Kedua cara tersebut akan diuraikan sebagai berikut:

\section{Pola Pembiasaan}

Dalam proses pembelajaran di sekolah baik secara disadari atau tidak guru dapat menanamkan sikap tertentu kepada siswa melalui proses pembiasaan. Misalnya siswa yang setiap kali menerima perlakuan yang tidak mengenakkan dari guru, seperti perilaku mengejek atau perilaku yang menyinggung perasaan anak, maka lama-kelamaan akan timbul rasa benci pada anak tersebut dan perlahan-lahan anak akan mengalihkan sikap negatif itu bukan hanya kepada gurunya itu sendiri akan tetapi juga kepada mata pelajaran yang diasuhnya.

\section{Modeling}

Pembentukan sikap seseorang dapat pula dilakukan melalui proses modeling, yaitu pembentukkan sikap melalui proses asimilasi atau proses mencontoh. Salah satu karakteristik anak didik yang sedang berkembang adalah keinginannya untuk melakukan peniruan. Hal yang ditiru itu adalah perilaku-perilaku yang diperagakan atau didemonstrasikan oleh orang yang menjadi idolanya. Prinsip peniruan ini yang dimaksud denngan modeling.

Menurut Azwar (2011, p.30) dalam interaksi sosialnya, individu be-reaksi membentuk pola sikap tertentu terhadap berbagai objek psikologis yang dihadapinya. Diantara berbagai faktor yang mempengaruhi pembentukan sikap adalah pengalaman pribadi, kebudayaan, orang lain yang dianggap penting, media massa, institusi atau lembaga pendidikan dan lembaga agama, serta faktor emosi dalam diri individu.

Untuk mengetahui sikap seseorang terhadap suatu objek dalam hal ini sikap terhadap matematika, beberapa ahli sudah mengkombinasikan bagian penting dari berbagai definisi sikap yang telah dikemukakan. Seperti dalam artikel yang berjudul "Attitude Measurement and Research", Aiken (Gable, 1986, p.5) mengkombinasikan defnisi-definisi tersebut sehingga didapatkan bahwa sikap memiliki komponen kognisi, afeksi dan performa.

Hal senada dinyatakan oleh Wagner (Gable, 1986, p.5) bahwa sikap terdiri dari komponen afektif, kognitif, dan perilaku yang masing-masing saling berhubungan untuk mengevaluasi pengetahuan seseorang dan kecenderungan untuk bertindak terhadap objek sikap. Demikian pula Ebel dan Frisbie (1986, p.320) menyatakan bahwa sikap memiliki tiga komponen, yaitu (1) bagian internal atau fisceral yang dirasa, (2) bagian kognitif yang dapat dinyatakan secara lisan atau tulisan, (3) komponen tindakan yang dinyatakan dengan perilaku nyata.

Menurut Azwar (2011, p.7) sikap seseorang terhadap suatu objek selalu berperanan sebagai perantara antara responsnya dan objek yang bersangkutan. Respons diklasifikasikan dalam tiga macam yaitu respons kognitif, respons afektif, serta respons perilaku atau konatif. Lebih lanjut dikatakan bahwa dengan melihat salah satu saja diantara ketiga bentuk respons tersebut, sikap seseorang sudah dapat diketahui. Walaupun begitu, deskripsi lengkap mengenai sikap individu tentu harus diperoleh dengan melihat ketiga macam respon secara lengkap. 


\section{METODE}

\section{Jenis Penelitian}

Jenis penelitan ini adalah penelitan kuasieksperimen dengan menggunakan pendekatan secara kuantitatif.

\section{Waktu dan Tempat Penelitian}

Tempat Pelaksanaan Penelitian

Penelitian ini dilaksanakan di SMP Negeri 6 Yogyakarta. Tempat pelaksanaan penelitian ini beralamat di Jalan RW Monginsidi 1 Yogyakarta.

\section{Waktu Pelaksanaan Penelitian}

Penelitian ini dilaksanakan selama 4 minggu dimulai pada tanggal 3 sampai dengan 25 Mei 2012. Waktu pelaksanaan penelitian ini sesuai dengan program pengajaran semester genap untuk kelas VIII. Total pertemuan pembelajaran selama penelitian ini 12 pertemuan dengan masing-masing pertemuan berdurasi 2 jam pelajaran (satu jam pelajaran sama dengan 40 menit). Rincian banyak waktu pertemuan pembelajaran adalah enam pertemuan untuk kelompok open-ended dan enam pertemuan untuk kelompok kontekstual.

\section{Target/Subjek Penelitian}

Populasi dalam penelitian ini adalah seluruh siswa kelas VIII SMP Negeri 6 Yogyakarta tahun pelajaran 2011/2012 yang terdiri dari tujuh kelas. Dari tujuh kelas tersebut dipilih dua kelas sebagai sampel penelitian. Pemilihan sampel didasarkan pada beberapa pertimbangan, yaitu disesuaikan dengan jadwal mengajar guru yang ditunjuk oleh kepala sekolah, secara umum kedua kelas tersebut identik dan kedua kelas mempunyai kemampuan sedang. Dari hal tersebut sampel pada penelitian ini ditetapkan siswa kelas VIIIE dan kelas VIIIF. Untuk selanjutnya kelas VIIIE diberi pembelajaran dengan pendekatan open-ended sedangkan kelas VIIIF diberi pembelajaran dengan pendekatan kontekstual. Untuk selanjutnya kelas VIIIF disebut kelompok open-ended dan kelas VIIIE disebut kelompok kontekstual

\section{Prosedur}

Pada penelitian ini digunakan dua kelompok dalam satu sekolah. Rancangan eksperimen yang digunakan adalah pretest-posttest, Nonequivalent Group Design. Pada desain ini kelompok eksperimen maupun kelompok kontrol tidak dipilih secara random, menyebabkan kedua kelompok tidak setara. Hal ini dapat dimaklumi sebab pada kenyataanya tidak memungkinkan untuk mengacak kelas sehingga kedua kelompok dipilih berdasarkan kelas yang ada, biasanya ditawarkan oleh guru atau kepala sekolah. Adapun rancangan eksperimen yang digunakan dalam penelitian ini secara skematis sebagai berikut (Wiersma, 1995, p.143)
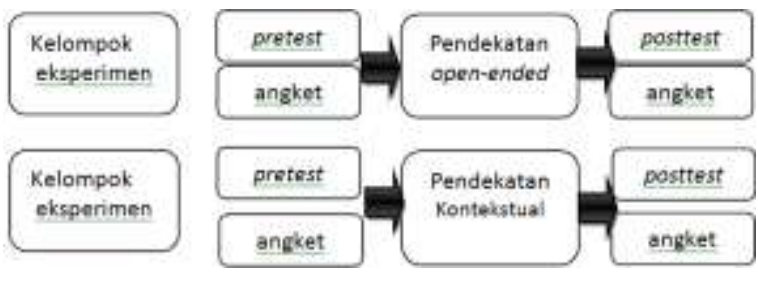

Gambar 1. Pretest-posttest, Nonequivalent group design

Langkah-langkah yang dilakukan dalam penelitan eksperimen berupa: (1) mengambil secara acak dua kelompok dari kelompok belajar (kelas) yang ada; (2) memberikan pretest (tes awal) dan angket pada kedua kelompok; (3) melakukan treatment dengan menerapkan pendekatan open-ended pada kelompok pertama dan pendekatan kontekstual pada kelompok kedua; (4) memberikan posttest (tes akhir) dan angket pada kedua kelompok.

\section{Data, Intrumen, dan Teknik Pengumpulan Data}

Teknik dan instrumen pengumpulan data dalam penelitian ini adalah sebagai berikut:

\section{Teknik Pengumpulan Data}

Teknik yang digunakan dalam pene-litian ini adalah Tes dan Angket. Tes digunakan untuk mengukur kemampuan pemecahan masalah matematis sedangkan angket digunakan untuk mengukur sikap siswa terhadap matematika.

Instrumen Pengumpulan Data

Instrumen yang digunakan dalam penelitian ini yaitu:

\section{Soal Uraian (Essay)}

Bentuk instrumen yang dipakai adalah soal uraian. Soal uraian memberikan indikasi yang baik untuk mengungkap kemampuan pemecahan masalah matematis, dan untuk mengetahui sejauh mana siswa mendalami suatu masalah yang diujikan. Soal uraian tersebut sebanyak lima item yang digunakan untuk mengukur kemampuan pemecahan masalah matematis sebelum perlakuan dan setelah perlakuan. 


\section{Daftar Pertanyaan}

Instrumen sikap disajikan dalam ben-tuk daftar pertanyaan. Daftar pertanyaan tersebut berbentuk cheklist. Daftar pertanyaan ini digunakan untuk mengetahui bagaimana sikap siswa terhadap matematika, pembelajaran matematika, dan guru matematika sebelum dan setelah dilakukan perlakuan.

\section{Teknik Analisis Data}

\section{Analisis Statistik Deskriptif}

Deskripsi data dilakukan melalui analisis deskriptif. Data yang dideskripsikan merupakan data yang diperoleh dari pengukuran pada variabel-variabel terikat yaitu kemampuan pemecahan masalah matematis dan sikap siswa terhadap matematika. Data yang telah diperoleh dihitung nilai rata-ratanya kemudian diinterpretasikan ke dalam kriteria-kriteria yang telah ditetapkan dan ditentukan persentasenya.

Data tentang kemampuan pemecahan masalah matematis diperoleh melalui pengukuran dengan instrumen tes yang berbentuk uraian. Skor yang diperoleh selanjutnya dikonversi sehingga menjadi nilai dengan rentang antara 0 sampai dengan 100. Skor tersebut kemudian digolongkan dalam kriteria berdasarkan Kriteria Ketuntasan Minimal (KKM) yang ditetapkan oleh sekolah untuk mata pelajaran matematika yaitu 68. Nilai KKM ini digunakan untuk menentukan persentase banyak siswa yang mencapai kriteria ketuntasan tersebut.

Data mengenai sikap terhadap matematika akan diperoleh dengan menggunakan instrumen non-tes yang berbentuk checklist dengan skala Likert. Penskoran untuk skala sikap siswa terhadap matematika menggunakan rentang skor antara 32 sampai dengan 160. Untuk menentukan kriteria hasil pengukurannya digunakan klasifikasi berdasarkan rata-rata ideal (Mi) dan Standar Deviasi ideal ( $\mathrm{Si})$.

$\mathrm{Mi}=(32+160) / 2=96$ dan $\mathrm{Si}=(160-32) / 6=$ 21,33

\section{Keefektifan Pendekatan Pembelajaran}

Data penelitian yang dianalisis adalah data kondisi awal dan akhir pada aspek kemampuan pemecahan masalah matematis dan sikap siswa terhadap matematika. Data kondisi awal untuk mengetahui gambaran awal kedua kelompok siswa, selanjutnya kondisi akhir untuk mendeskripsikan keefektifan pendekatan open-ended dan pendekatan kontekstual terhadap kemapuan pemecahan masalah dan sikap siswa terhadap matematika.

kriteria keputusan yaitu tolak $\mathrm{H}_{0}$ jika $t$ hitung $>t_{\alpha ; n-1}$. Untuk variabel kemampuan pemecahan masalah matematis, nilai $\mu_{\alpha}$ adalah 68 skala 0 - 100. Nilai ini ditentukan berdasarkan pertimbangan bahwa KKM yang ditetap-kan untuk mata pelajaran matematika di SMPN 6 Yogyakarta adalah 68, sehingga peneliti menetapkan 68 sebagai standar untuk menentukan efektif tidaknya pendekatan open-ended dan pendekatan kontekstual yang diterapkan pada aspek kemampuan pemecahan masalah matematis.

Untuk variabel sikap terhadap matematika, nilai $\mu_{o}$ yang digunakan pada rumus di atas adalah 118 skala 32 - 160. Merujuk pada kriteria untuk sikap, nilai ini termuat dalam kriteria baik dan merupakan nilai tengah pada interval skor untuk kriteria tersebut. Nilai ini menjadi standar untuk menentukan efektif tidaknya pendekatan open-ended dan pendekatan kontekstual yang diterapkan pada aspek sikap siswa terhadap matematika.

Komparasi Pengaruh Pendekatan Pembelajaran

Asumsi yang harus terpenuhi sebelum melakukan analisis dengan one sample t-test dan Multivariate two-group test (Hotelling's $T^{2}$ ) adalah asumsi normalitas dan homogenitas sebagai berikut

\section{Uji Normalitas}

Uji normalitas bertujuan untuk mengetahui apakah sampel berasal dari populasi yang berdistrubusi normal. Uji normalitas dilakukan terhadap data yang diperoleh baik sebelum maupun setelah treatment meliputi data hasil tes (kemampuan pemecahan masalah matematis) dan angket sikap terhadap matematika baik pada kelompok yang menerapkan pendekatan openended maupun pendekatan kontekstual

\section{Uji Homogenitas}

Untuk mengetahui homogenitas matriks varian kovarians dua kelompok dengan dua variabel dependen secara simultan dilakukan melalui uji homogenitas Box-M, meng-gunakan bantuan software SPSS 16.0. Uji homogenitas dan penarikan kesimpulan terhadap uji hipotesis dilakukan pada taraf signifikansi 0,05 . Pedoman pengambilan keputusan uji homogenitas sebagai berikut: (1) jika nilai signifikansi atau nilai probabilitas kurang dari 0,05 maka dapat disimpul- 
kan data tidak berasal dari populasi-populasi yang mempunyai matrik varians kovarian yang homogen.

\section{Pengujian hipotesis}

Setelah melakukan analisis dengan one sample t-test, analisis dilanjutkan dengan multivariate two-group test dengan bantuan program SPSS 17.0 for windows. Teknik analisis ini digunakan untuk melihat adanya perbedaan mean antara dua kelompok yaitu kelompok yang menggunakan pendekatan open-ended dan kontekstual dengan dua variabel dependen yaitu kemampuan pemecah-an masalah matematis, dan sikap siswa terhadap matematika secara si- multan. Untuk analisis dengan Multivariate twogroup test (Hotelling's $T^{2}$ ), data yang dianalisis adalah data yang diperoleh dari pretest, posttest, dan angket sikap.

\section{HASIL DAN PEMBAHASAN}

\section{Hasil Penelitian}

Deskripsi Data

\section{Data Hasil Tes Kemampuan Pemecahan Masa- lah Matematis}

Secara ringkas hasil tes kemampuan pemecahan masalah matematis pada kedua kelompok disajikan pada Tabel 1 berikut:

Tabel 1. Deskripsi Data Hasil Kemampuan Pemecahan Masalah Matematis

\begin{tabular}{ccccc}
\hline Deskripsi & Open-Ended & Kontekstual & & \\
\cline { 2 - 5 } & Pretest & Postest & Pretest & Postest \\
Rata-rata & 37,06 & 79,71 & 35,78 & 75,20 \\
Standar Deviasi & 17,40 & 7,58 & 19,11 & 7,75 \\
Varians & 302,87 & 57,49 & 365,19 & 60,06 \\
Skor minimum & 13,33 & 60,00 & 0,00 & 63,33 \\
Skor maksimum & 73,33 & 96,67 & 66,67 & 96,67 \\
ketuntasan & $5,88 \%$ & $97,06 \%$ & $8,82 \%$ & $91,18 \%$ \\
Peningkatan ketuntasan & $91,18 \%$ & $82,36 \%$ & & \\
\hline
\end{tabular}

Keterangan: Nilai berskala $0-100$

\section{Data Hasil Angket Sikap Siswa terhadap Matematika}

Sebelum dan setelah diberikan treatment pada kedua kelompok eksperimen, dilakukan pengukuran sikap siswa terhadap matematika. Data yang diperoleh kemudian dianalisis dengan statistik deskriptif. Deskripsi data hasil angket sikap siswa sebelum dan setelah treatment disajikan pada Tabel 2 berikut:

Tabel 2. Deskripsi Data Hasil Angket Sikap Siswa

\begin{tabular}{ccccc}
\hline \multirow{2}{*}{ Deskripsi } & \multicolumn{2}{c}{ Open-Ended } & \multicolumn{2}{c}{ Kontekstual } \\
\cline { 2 - 5 } & Pretest & Postest & Pretest & Postest \\
\hline $\begin{array}{c}\text { Rata-rata } \\
\text { Standar } \\
\text { deviasi }\end{array}$ & 106,76 & 121,68 & 105,18 & 120,89 \\
Varians & 41,45 & 6,74 & 7,40 & 5,86 \\
$\begin{array}{c}\text { Skor } \\
\text { minimum }\end{array}$ & 95 & 110 & 93 & 112 \\
$\begin{array}{c}\text { Skor } \\
\text { maksimum }\end{array}$ & 121 & 133 & 120 & 132 \\
\hline
\end{tabular}

Keterangan: skor taksiran berskala 32-160
Analisis Data

\section{Data Sebelum Treatment}

Data yang diperoleh sebelum treatment meliputi data hasil pretest pemecahan masalah matematis dan sikap siswa terhadap matematika baik untuk kelompok open-ended maupun kelompok kontekstual.

\section{Uji Normalitas}

Pengujian normalitas secara multivariat dengan menggunakan jarak Mahalonobis. Analisis dilakukan secara manual menggunakan bantuan program Excel 2010. Gambar scaterplot uji normalitas populasi sebelum treatment untuk kelompok dengan pendekatan open-ended dan dengan pendekatan kontekstual disajikan pada Gambar 2 dan Gambar 3 sebagai berikut: 


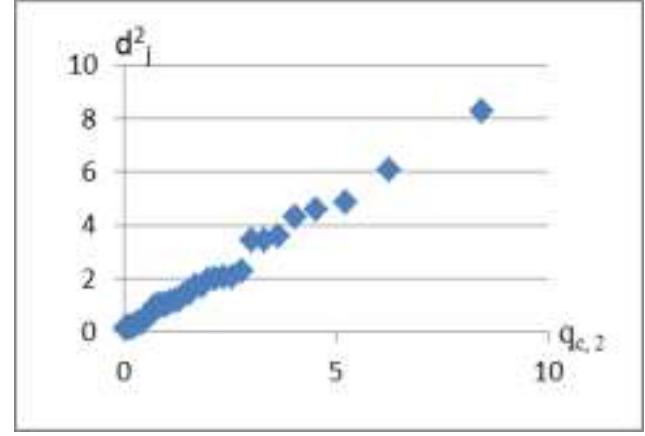

Gambar 2. Hasil Scaterplot Normalitas Pretest KPMM dan Sikap Kelompok dengan Pendekatan Open-ended

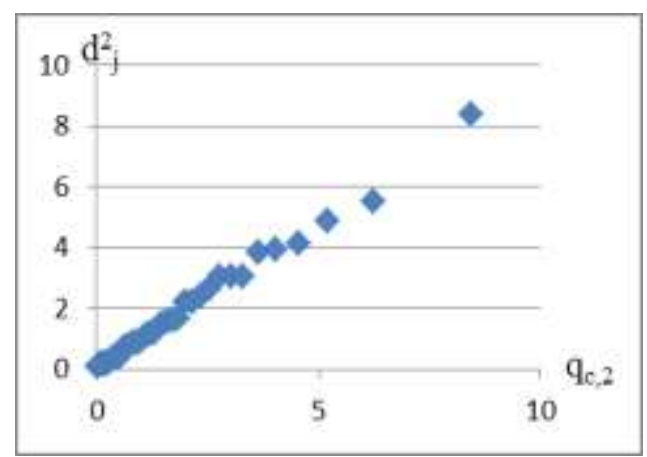

Gambar 3. Hasil Scaterplot Normalitas Pretest KPMM dan Sikap Kelompok dengan Pendekatan Kontekstual

Berdasarkan Gambar 2 dan Gambar 3 terlihat bahwa scater plot cenderung membentuk garis lurus. Dengan demikian asumsi normalitas terpenuhi.

\section{Uji Homogenitas Matriks Varians-kovarians}

Untuk uji homogenitas disajikan dalam Tabel 3 berikut:

Tabel 3. Hasil Uji Homogenitas Multivariat Data Sebelum Treatment

\begin{tabular}{ccccc}
\hline Box's $\boldsymbol{M}$ & $\mathbf{F}$ & $\mathbf{d f}_{\mathbf{1}}$ & $\mathbf{d f}_{\mathbf{2}}$ & Signifikansi \\
\hline 2,161 & 0,697 & 3 & $0,784 \mathrm{E} 6$ & 0,554 \\
\hline
\end{tabular}

Berdasarkan Tabel 3, tampak bahwa signifikansi yang diperoleh adalah 0,554 dan bernilai lebih dari 0,05 . Ini menunjukkan bahwa matrik varians-kovarians kelompok dengan pendekatan open-ended dan dengan pendekatan kontekstual homogen.

Uji kesamaan Mean Kelompok Open-ended Dibandingkan Kelompok Kontekstual (Uji Multivariat)

Hasil uji kesamaan mean pembelajaran dengan pendekatan open-ended dan pembelajaran menggunakan pendekatan kontekstual sebe- lum treatment dapat dilihat pada Tabel 4 berikut:

Tabel 4. Hasil Uji Kesamaan Vektor Rata-rata Kelompok dengan Pendekatan Open-Ended dan Pendekatan Kontekstual

\begin{tabular}{cccccc}
\hline Tes name & Value & F & $\begin{array}{c}\text { Hypothesis } \\
\text { df }\end{array}$ & $\begin{array}{c}\text { Error } \\
\text { df }\end{array}$ & Sig \\
\hline $\begin{array}{c}\text { Wilks } \\
\text { Lamda }\end{array}$ & 0,987 & $0,441^{\mathrm{a}}$ & 2,000 & 65 & 0,646 \\
\hline
\end{tabular}

Dari Tabel 4 dapat diketahui bahwa signifikansi yang diperoleh adalah 0,646 dan bernilai lebih dari 0,05 . Ini menunjukkan bahwa $\mathrm{H}_{0}$ diterima. Oleh sebab itu dapat disimpulkan bahwa kemampuan pemecahan masalah dan sikap siswa terhadap matematika kelompok open-ended tidak berbeda dengan kemampuan pemecahan masalah dan sikap siswa terhadap matematika kelompok kontekstual

\section{Data setelah Treatment}

Data hasil penelitian berupa skor kemampuan pemecahan masalah matematis dan skor sikap setelah treatment, yang kemudian dianalisis untuk menguji hipotesis penelitian. Sebelum dilakukan uji hipotesis, maka dilakukan uji Normalitas dan uji Homogenitas.

\section{Uji Normalitas}

Pengujian normalitas secara multivariat dengan menggunakan jarak Mahalonobis. Analisis dilakukan secara manual menggunakan bantuan program Excel 2010. Gambar scaterplot uji normalitas populasi setelah treatment untuk kelompok dengan pendekatan open-ended dan dengan pendekatan kontekstual disajikan sebagai berikut:

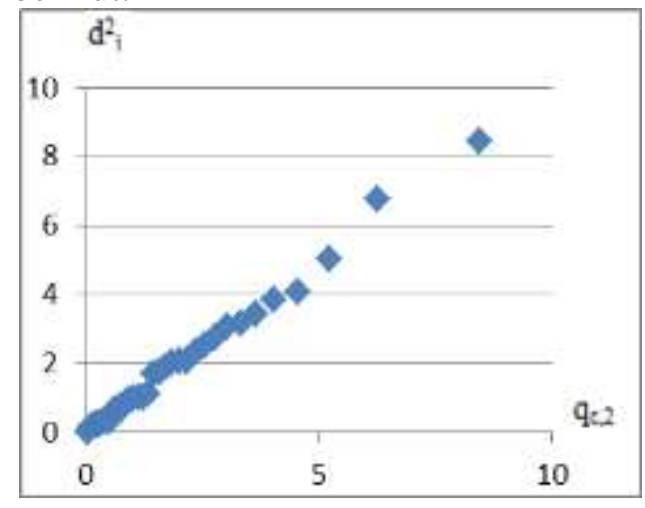

Gambar 4. Hasil Scaterplot Normalitas Posttest KPMM dan Sikap Kelompok dengan Pendekatan Open-ended 


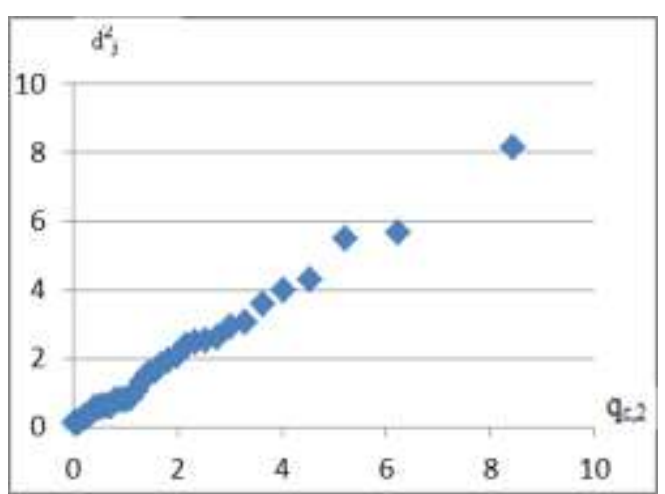

Gambar 5. Hasil Scaterplot Normalitas Posttest

KPMM dan Sikap Kelompok dengan

Pendekatan Kontekstual

Berdasarkan gambar 4 dan 5 terlihat bahwa scaterplot cenderung membentuk garis lurus. Dengan demikian asumsi normalitas terpenuhi.

\section{Uji Homogenitas Matriks Varians-kovarians} berikut ini.

Uji homogenitas disajikan dalam Tabel 5

Tabel 5. Hasil Uji Homogenitas Multivariat Data Setelah Treatment

\begin{tabular}{ccccc}
\hline Box's $\boldsymbol{M}$ & $\mathbf{F}$ & $\mathbf{d f}_{\mathbf{1}}$ & $\mathbf{d f}_{\mathbf{2}}$ & Signifikansi \\
\hline 5,662 & 1,825 & 3 & $0,784 \mathrm{E} 6$ & 0,140 \\
\hline
\end{tabular}

Berdasarkan Tabel 5, tampak bahwa signifikansi yang diperoleh adalah 0,140 dan bernilai lebih dari 0,05 . Ini menunjukkan bahwa matriks varians-kovarians kelompok dengan pendekatan open-ended dan pendekatan kontekstual homogen.

Uji Keefektifan Pembelajaran dengan Pendekatan Open-Ended dan Kontekstual (One Sample ttest)

Uji keefektifan ini bertujuan untuk mengetahui efektif tidaknya pembelajaran dengan pendekatan open-ended dan pembelajaran dengan pendekatan kontekstual masing-masing pada aspek kemampuan pemecahan masalah matematis dan sikap siswa terhadap matematika.
Tabel 6. Hasil Uji Keefektifan Pembelajaran dengan Pendekatan Open-ended dan Pembelajaran dengan Pendekatan Kontekstual

\begin{tabular}{ccc}
\hline Kelompok & Variabel & $\mathbf{t}_{\text {hitung }}$ \\
\hline pendekatan & pemecahan masalah & 9,00 \\
open-ended & Sikap & 3,18 \\
$\mathrm{t}_{\text {Tabel }}$ & 2,03 & \\
pendekatan & pemecahan masalah & 5,41 \\
kontekstual & Sikap & 2,87 \\
$\mathrm{t}_{\text {Tabel }}$ & 2,03 & \\
\hline
\end{tabular}

Berdasarkan Tabel 6, pada kelompok dengan pendekatan open-ended untuk variabel kemampuan pemecahan masalah matematis diperoleh nilai $\mathrm{t}_{\text {hitung }}=9,00>\mathrm{t}_{\text {Tabel }}=2,02$, untuk variabel sikap siswa terhadap matematika diperoleh nilai $t_{\text {hitung }}=3,18$. Kedua nilai $t_{\text {hitung }}$ ini menunjukkan bahwa hasil yang diperoleh signifikan karena nilai $\mathrm{t}_{\text {hitung }}$ tersebut lebih besar dari $\mathrm{t}_{\text {Tabel }}=$ 2,02. Dengan demikian, pembelajaran dengan pendekatan open-ended efektif pada aspek kemampuan pemecahan masalah matematis dan sikap siswa terhadap matematika.

Pada kelompok dengan menggunakan pendekatan kontekstual untuk variabel kemampuan pemecahan masalah matematis diperoleh nilai $t_{\text {hitung }}=5,41$ untuk variabel sikap siswa terhadap matematika diperoleh nilai $t_{\text {hitung }}=2,87$. Kedua nilai $t_{\text {hitung }}$ ini menunjukkan bahwa hasil yang diperoleh signifikan karena nilai-nilai tersebut lebih besar dari $t_{\text {Tabel }}=2,03$. Dengan demikian, sebagaimana pembelajaran dengan pendekatan open-ended, pembelajaran menggunakan pendekatan kontekstual efektif baik pada aspek kemampuan pemecahan masalah matematis dan sikap siswa terhadap matematika.

Uji Kesamaan Mean Kelompok Open-Ended Dibandingkan Kelompok Kontekstual Setelah Treatment

Uji kesamaan keefektifan pembelajaran dengan pendekatan open-ended dan pembelajaran menggunakan pendekatan kontekstual setelah treatment dapat dilihat pada Tabel 7 berikut:

Tabel 7. Hasil Uji Perbandingan Pembelajaran dengan Pendekatan Open-ended dan

Pembelajaran Menggunakan Pendekatan Kontekstual

\begin{tabular}{cccccc}
\hline Tes name & Value & F & $\begin{array}{c}\text { Hypothesis } \\
\text { df }\end{array}$ & $\begin{array}{c}\text { Error } \\
\text { df }\end{array}$ & Sig \\
\hline $\begin{array}{c}\text { Wilks } \\
\text { Lamda }\end{array}$ & 0,892 & $3,954^{\mathrm{a}}$ & 2,000 & 65 & 0,024 \\
\hline
\end{tabular}


Berdasarkan Tabel 7, tampak bahwa F hitung $=3,954^{\mathrm{a}}$, signifikansi yang diperoleh adalah 0,024 dan bernilai kurang dari 0,05 . Ini menunjukkan bahwa $\mathrm{H}_{0}$ ditolak. Dengan demikian, dapat disimpulkan bahwa terdapat perbedaan keefektifan antara kelompok dengan pendekatan open-ended dan kelompok dengan pendekatan kontekstual pada aspek kemampuan pemecahan masalah matematis dan sikap siswa terhadap matematika.

\section{Uji Univariat}

Hasil analisis terhadap perbedaan pemecahan masalah matematis kedua kelompok diperoleh $t_{\text {hitung }}$ sebesar 2,43 , kemudian $t_{\text {Tabel }}$ sebesar 2,29 atau $t_{\text {hitung }}=2,43>\mathrm{t}_{0,025,66}=2,29$, sehingga dapat disimpulkan $\mathrm{H}_{0}$ ditolak. Dengan kata lain pembelajaran menggunakan pendekatan open-ended lebih efektif dari pembelajaran dengan pendekatan kontekstual pada aspek kemampuan pemecahan masalah matematis.

Untuk sikap siswa terhadap matematika didapat $t_{\text {hitung }}$ sebesar 0,52 kemudian $t_{\text {Tabel }}$ sebesar 2,29 atau $\mathrm{t}_{\text {hitung }}=0,52<\mathrm{t}_{0,025,66}=2,29$, sehingga dapat disimpulkan $\mathrm{H}_{0}$ diterima. Dengan demikian kelompok pendekatan openended tidak lebih efektif dari pendekatan kontekstual pada aspek sikap siswa terhadap matematika.

\section{Pembahasan}

Keektifitan Pembelajaran dengan Pendekatan Open-ended dan Pendekatan Kontekstual

Berdasarkan kriteria ketuntasan yang telah ditetapkan dan setelah dilakukan uji statistik dengan uji one sample t-test, pembelajaran matematika dengan pendekatan open-ended efektif pada aspek kemampuan pemecahan masalah matematis dan sikap siswa terhadap matematika. Hal ini disebabkan karena partisipasi aktif siswa dalam mengikuti pembelajaran matematika melalui diskusi dengan anggota kelompoknya. Dalam pembelajaran open-ended siswa diberikan kesempatan melalui LKS untuk mengembangkan pemikiran matematika secara independen kemudian secara berkelompok saling bertukar ide dan menjelaskan ide masing-masing dalam penyelesaian soal. Dalam hal ini setelah siswa mengerjakan soal secara sendiri-sendiri kemudian sharing secara berkelompok. Hal ini menyebabkan banyak cara penyelesaian dan jawaban benar yang menimbulkan rasa ingin tahu bagaimana cara siswa lain mengkonstruksi/melengkapi soal tersebut hingga menemukan solusi/ penyelesaian akhir. Dengan pendekatan ini menyebabkan mereka lebih banyak berdikusi, saling bertukar ide bahkan sampai berdebat didalam anggota kelompoknya. Disinilah siswa terlibat dalam proses matematika seperti spesialisasi, eksplorasi, conjecturing, diversifikasi, dan generalisasi yang akan meningkatkan kemampuan pemecahan masalah lebih baik. Dengan demikian pembelajaran dengan pendekatan open-ended efektif terhadap kemampuan pemecahan masalah matematis dan sikap siswa terhadap matematika.

Pada kelas lain diterapkan pembelajaran dengan pendekatan kontekstual. Berdasarkan kriteria keputusan pada one sample t-test maka pembelajaran matematika dengan pendekatan kontekstual efektif di tinjau dari kemampuan pemecahan masalah dan sikap siswa terhadap matematika. Hal ini disebabkan siswa berpartisipasi aktif dalam pembelajaran matematika melalui LKS untuk menyelesaikan rangkaian masalah kontekstual. Di dalam kelas kontekstual para siswa belajar untuk menemukan makna dalam pelajaran mereka dengan cara menghubungkan materi akademik dengan konteks kehidupan keseharian mereka. Keterkaitan yang mengarah pada makna ini adalah bagian terpenting dalam pembelajaran kontekstual, karena dengan makna akan memberi alasan mereka untuk belajar sehingga kesungguhan untuk belajar semakin baik. Dalam proses pembelajaran, siswa akan membuat hubungan-hubungan penting yang menghasilkan makna dengan melaksanakan pembelajaran yang di dalamnya terdapat komponen-komponen CTL. Komponen tersebut meliputi konstruktivisme, menemukan, modeling, bertanya, masyarakat belajar, refleksi, dan penilaian autentik. Pembelajaran kontekstual ini dapat mengaktifkan siswa dalam melakukan eksplorasi terhadap model kemudian siswa membangun ide-ide matematis melalui interaksi dalam masyarakat belajar (diskusi). Disinilah siswa terlibat dalam proses matematika seperti spesialisasi, eksplorasi, conjecturing, dan generalisasi yang akan meningkatkan kemampuan pemecahan masalah lebih baik. Dengan demikian pembelajaran dengan pendekatan kontektual efektif terhadap kemampuan pemecahan masalah matematis dan sikap siswa terhadap matematika.

Berdasarkan uraian tersebut dapat disimpulkan bahwa kedua pendekatan pembelajaran baik pendekatan open-ended dan pendekatan kontekstual efektif terhadap kemampuan pemecahan masalah matematis dan sikap siswa terhadap matematika. 
Perbedaan Pengaruh Pembelajaran Matematika dengan Pendekatan Open-Ended dan Pendekatan Kontekstual

Berdasarkan hasil analisis menggunakan uji-t ditemukan: Pertama, uji univariat untuk variabel kemampuan pemecahan masalah matematis ditemukan nilai probabilitas lebih kecil dari taraf signifikansi maka hipotesis nol $\left(\mathrm{H}_{0}\right)$ yang menyatakan "Pembelajaran dengan pendekatan open-ended tidak lebih efektif dibanding pendekatan kontekstual pada aspek kemampuan pemecahan masalah matematis" ditolak. Berarti, kemampuan pemecahan masalah matematis sebagai hasil dari mengikuti pelajaran matematika dengan pendekatan open-ended lebih tinggi daripada kemampuan pemecahan masalah matematis siswa sebagai hasil mengikuti pelajaran matematika dengan menggunakan pendekatan kontekstual.

Kedua, adanya perbedaan ini disebabkan oleh kegiatan siswa yang lebih aktif di dalam kegiatan pembelajaran open-ended. Berdasarkan pengamatan di kelas, seorang siswa yang mendapatkan masalah terbuka, dalam menyelesaikan soal, kegiatannya dalam hal ini praktik, mengamati, menulis dan berdiskusi tidak selesai hanya sampai mendapatkan jawaban akhir saja, melainkan mereka terus menggali pemahaman mereka baik terhadap cara penyelesaian yang dilakukan oleh teman sekelompok maupun dengan cara merubah sendiri situasi soal yang ada pada LKS sehingga tidak ada waktu terbuang untuk santai. Disamping itu melalui proses penyelesaian soal yang dilakukan siswa, dapat memberikan petunjuk kepada guru untuk melihat tingkat kemampuan kognitif yang dimiliki masing-masing siswa. Hal ini sudah tentu diketahui siswa, oleh karenanya siswa yang lebih pintar akan berupaya menyelesaikan soal dengan cara yang lebih komplek yang mungkin tidak dapat dilakukan oleh siswa yang lain. Hal ini akan memotivasi mereka untuk berlomba-lomba dalam mempelajari matematika. Kegiatan pembelajaran tersebut merupakan proses-proses kegiatan pembelajaran yang memungkinkan seorang siswa memperoleh kemampuan pemecahan masalah matematis lebih mendalam. Sedangkan pada pembelajaran kontekstual, siswa yang diberikan masalah tertutup cenderung mengakhiri kegiatan belajarnya dengan bersantai setelah menyelesaikan soal yang ada pada LKS. Dalam hal ini siswa merasa sudah cukup puas karena telah menyelesaiakan soal dengan baik. Sehingga kemampuan pemecahan masalah sis- wa tidak begitu mendalam sebagaimana pada pembelajaran open-ended.

Ketiga, pada uji univariat untuk variabel sikap didapatkan nilai probabilitas lebih besar dari taraf signifikansi maka hipotesis nol $\left(\mathrm{H}_{0}\right)$ yang menyatakan "Pembelajaran dengan pendekatan open-ended tidak lebih efektif dibanding pendekatan kontekstual pada aspek sikap siswa terhadap matematika" diterima. Berarti, sikap siswa terhadap matematika sebagai hasil dari mengikuti pelajaran matematika dengan pendekatan open-ended sama efektif dengan sikap siswa terhadap matematika sebagai hasil mengikuti pelajaran matematika dengan menggunakan pendekatan kontekstual.

Adanya kesamaan keefektifan ini bukan berarti bahwa kedua pendekatan ini sama efeknya terhadap sikap siswa. Hal ini disebabkan diawal pembelajaran open-ended, para siswa akan merasa heran disebabkan mereka harus membuat pertanyaan sendiri sekaligus menjawab pertanyaan tersebut. Kegiatan ini justru membuat sikap mereka menjadi negatif terhadap pembelajaran open-ended disebabkan tidak terbiasa dan sering mengalami kesulitan dalam menyelesaikan masalah. Berdasarkan pengamatan di kelas di awal pembelajaran sebagian siswa kebingungan dalam menghadapi soal-soal openended karena tidak terbiasa secara mandiri dalam menentukan nilai/angka yang harus dilengkapi pada soal yang diberikan. Akan tetapi pada pertemuan berikutnya secara perlahan siswa sudah mulai terbiasa dan bisa memahami serta mengikuti alur dalam pembelajaran open-ended. Bahkan hari-hari berikutnya sebagian besar siswa sudah senang dengan pembelajaran ini. Akan tetapi sangat disayangkan pembelajaran openended harus berakhir di saat siswa mulai menyukai pembelajaran ini karena pembelajarannya berlangsung singkat yaitu hanya enam kali pertemuan. Berbeda dengan pembelajaran kontekstual dimana sejak awal pembelajaran, siswa sudah menyukai pembelajaran ini, tinggal bagaimana meningkatkannya. Kalau dianalogikan dalam pembelajaran open-ended sikap siswa start mulai dari negatif ke positif sedangkan dalam pembelajaran kontekstual sikap siswa start mulai dari nilai positif ke nilai yang lebih tinggi. Hal inilah yang merupakan salah satu faktor penyebab keefektifan pembelajaran openended ditinjau dari sikap siswa tidak lebih efektif dari pada pembelajaran kontekstual. 


\section{SIMPULAN DAN SARAN}

\section{Simpulan}

Berdasarkan analisis data dan pembahasan, maka dapat disimpulkan sebagai berikut: (1) pendekatan open-ended dan kontekstual dalam pembelajaran matematika efektif pada aspek kemampuan pemecahan masalah matematis dan sikap siswa terhadap matematika siswa kelas VIII SMPN 6 Yogyakarta, (2) terdapat perbedaan keefektifan secara signifikan pada penerapan pendekatan open-ended dan pendekatan kontekstual dalam pembelajaran matematika materi pokok bangun ruang sisi datar pada aspek kemampuan pemecahan masalah matematis dan sikap siswa terhadap matematika. Dari hasil uji lanjut menunjukkan bahwa: (a) pendekatan open-ended lebih efektif dibandingkan pendekatan kontektual pada aspek kemampuan pemecahan masalah matematis siswa, (b) pendekatan open-ended tidak lebih efektif dibandingkan pendekatan kontektual pada aspek sikap siswa terhadap matematika

\section{Saran}

Kepada para Guru

Pembelajaran matematika dengan pendekatan open-ended dan kontekstual efektif apada aspek kemampuan pemecahan masalah matematis dan sikap siswa SMPN 6 Yogyakarta pada materi bangun ruang sisi datar. Oleh sebab itu disarankan kepada para guru agar menggunakan pendekatan open-ended dan kontekstual dalam pembelajaran matematika di kelas. Sebab dengan menggunakan pendekatan open-ended kemampuan pemecahan masalah siswa dapat meningkat lebih baik, sedangkan dengan menggunakan pendekatan kontekstual lebih cepat dalam meningkatkan sikap positif siswa terhadap matematika.

Kepada para Calon Peneliti

Penelitian hanya terfokus pada penerapan pendekatan open-ended dan pendekatan kontekstual terhadap kemampuan pemecahan masalah dan sikap siswa, bagaimana situasinya bila kedua pembelajaran tersebut digunakan untuk mengukur aspek lain seperti kemampuan berpikir kritis dan kreatif

Analisis yang digunakan dalam penelitian ini hanya dilakukan secara kuantitatif. Disarankan bagi peneliti berikutnya agar selain menggunakan analisis secara kuantitatif, juga menggunakan analisis secara kualitatif agar data yang dihasilkan lebih akurat karena bisa saling melengkapi.

\section{DAFTAR PUSTAKA}

Azwar, Saifuddin. (2011). Sikap manusia teori dan pengukurannya. Yogyakarta: Pustaka Belajar.

Berns, R.G \& Erickson, P.M. (2001). Contextual teaching and learning: preparing students for the new economy. Artikel. Diambil pada tanggal 4 Januari 2012, dari http://www.cord.org/uploadedfiles/NCCTE_Highlight05-ContextualTeachingLearning.pdf.

Boediono. (2004). Statistika dan probabilitas. Bandung: Remaja Rosdakarya

Brumbaught, D.K., Rock, D., Brumbaught, L.S., et al. (2003). Teaching k-6 mathematics. Mahwah: Lawrence Erlbaum Associates, Publishers.

Dahar, R. W. (1989). Teori-teori belajar. Jakarta: Erlangga.

Eagly, A. H. \& Chaiken, S. (1993). The psychology of attitudes. New York: Harcourt Brace Jovanovich.

Ebel, R.I. \& Frisbie, D.A. (1986). Essential of educational measurement. Englewood Cliffs: Prentice-Hall, Inc.

Gable, R.K. (1986). Instruments development in the affective doman. Buston: Kliewe Nijhoff Publishing.

Haylock, D \& Thangata, F. (2007). Key concepts in teaching primary mathematics. London: Sage Publications.

Herman, Tatang. (2007). Membangun pengetahuan siswa melalui pembelajaran berbasis masalah. Artikel. Diambil pada tanggal 14 Januari 2012, dari http://file.upi.edu/Direktori/FPMIPA/JU R._PEND._MATEMATIKA/196210111 991011-

TATANG_HERMAN/Artikel/mkalah2taher.pdf.

Hino, K. (2007). Toward the problem-centered classroom: trends in mathematical problem solving in Japan. Artikel. Diambil pada tanggal 3 Desember 2011, dari http://cimm.ucr.ac.cr/ciaemIngles/articul os/universitario/conocimiento/Toward\% 20the\%20problem- 
centered $\% 20$ classroom: $\% 20$ trends $\% 20$ in $\% 20$ mathematical\%20problem\%20solvi ng\%20in\%20Japan*Hino,\%20Keiko\%2 0 *Keiko\%20Hino.pdf

Johnson, E. B. (2002). Contextual teaching and learning: what it is and why it's here to stay. Thousand Oaks, California: Corwin Pres, Inc.

Johnson, E. B. (2007). Contextual teaching and learning: Menjadikan kegiatan belajarmengajar mengasyikkan dan bermakna. $\left(3^{r d} e d.\right)$. (Terjemahan Ibnu Setiawan). California: Corwin Pres, Inc.(Buku asli diterbitkan tahun 2002)

Kompasiana. (2012). Kurikulum 2013 vs kemampuan berpikir anak. Artikel. Diambil pada tanggal 6 Januari 2013, dari http://edukasi.kompasiana.com/2012/12/ 19/kurikulum-2013-vs-kemampuanberpikir-anak--517937.html.

Mayer, R.E. \& Wittrock, M.C. Problem solving. In Alexander, P. A. \& Winne, P. H. (eds.). (2006). Handbook of educational psychology. Mahwah: Lawrence Erlbaum Associates, Inc.

McIntosh, R. \& Jarret, D. (2000). Teaching mathematical problem solving: implementing the vision. New York: NWREL, Mathematics and Science Education Center.

Muslich, Masnur. (2007). KTSP pembelajaran berbasis kompetensi dan komtekstual panduan bagi guru, kepala sekolah, dan pengawas sekolah. Jakarta: Bumi Aksara.

Neale, D.C. (1969). The role of attitudes in learning mathematics. Artikel. Diambil pada tanggal 10 Februari 2012, dari http://www.jstor.org/discover/10.2307/4 1187564 ?uid $=3738224 \&$ uid $=2$ \&uid $=4 \&$ sid $=21101498124003$.

Nitko, A.J. \& Brookhart, S.M. (2007). Educational assessment of student. Upper Saddle River: Pearson Education,Inc.

Nohda, N. (2000). A study of "open-approach" method in school mathematics teaching focusing on mathematical problem solving activities. Artikel. Diambil pada tanggal 9 November 2011, dari http://www.nku.edu/ sheffield/nohda.ht $\mathrm{ml}$.

Orton, A. (2006). Learning mathematics issues, theory and classroom practice $\left(3^{\text {rd }} \mathrm{ed}.\right)$. London: Cassell.

Pehkonen, E. (1997). The state-of-art in mathematical creativity. dalam $\mathrm{zdm}$. international reviews on mathematical education. Artikel. Diambil pada tanggal 29 Desember 2011, dari http://www.emis.de/journals/ZDM/zdm9 73a1.pdf.

Pehkonen, E. (Oktober 1999). Open-ended problems: A method for an educational change. Makalah disajikan dalam $4^{\text {th }}$ Pan-Hellenic Conference With International Participation Didactics Of Mathematics \& Informatics In Education, di The University of Crete: Department for Primary Education, Department of Computer Science, Department of Mathematics.

Polya, G. (1981). Mathematical discovery on understanding, learning, and teaching problem solving. Canada: John \& Sons.

Polya, G. (1985). How to solve it . A new aspect of mathematical method $\left(2^{\text {nd }} e d\right.$.). Princeton : Princeton University Press.

Quinones, B.F. (1996). The effect of computer use on mathematical reasoning, problem solving skills and attitudes at the college level. Artikel. Diambil pada tanggal 17 April 2012, dari http://ponce.inter.edu/cai/tesis/bfeliciano -index.html

Rusgianto, H.S. (2006). Hubungan antara sikap terhadap matematika, kecerdasan emosional dalam interaksi sosial di kelas dengan hasil belajar matematika siswa smp negeri 5 yogyakarta tahun 2006. Naskah dipresentasikan dalam Seminar Nasional Matematika dan Pendidikan Matematika 2006 dengan tema "Trend Penelitian dan Pembelajaran Matematika di Era ICT “ yang diselenggarakan pada tanggal 24 Nopember 2006.

Sanjaya, Wina. (2007). Strategi pembelajaran: berorientasi standar proses pendidikan. Jakarta: Kencana.Schoenfeld, A.H. (1985). Mathematical problem solving. New York: Academic Press, Inc. 
Shadiq, Fadjar. (2008). Bagaimana cara guru memanfaatkan faktor sikap dalam pembelajaran matematika. Artikel. Diambil pada tanggal 11 Desember 2011, dari http://fadjarp3g.files.wordpress.com/200 8/12/08-afektif_limas_1.pdf.

Sternberg, R.J. \& Ben-Zeev, T. (1996). The nature of mathematical thinking. Mahwah, NJ: Lawrence Erlbaum Associates, Inc.

Strategic Review. (2011). Rethinking Indonesia's educational paradigm: learning from the world. Artikel. Diambil pada tanggal 26 Mei 2012, dari http://www.sr-indonesia.com/thismonths-issue/global-perspectives/206rethinking-indonesias-educationalparadigm-learning-from-the-world.

Suherman, Erman., Turmudi, Suryadi, Didi. dkk. (2003). Strategi pembelajaran matematika kontemporer. Bandung: JICA UPI.

Sullivan, P., Bourke, D., \& Scott, A. (1995). Open-ended tasks as stimuli for learning mathematics. In S. Flavel (Ed.)
Proceedings of the 18th Annual Conference of the Mathematics Research Group of Australasia (pp. 484-493), Darwin, Australia.

Taplin, M. (1998). Mathematics through problem solving. Artikel. Diambil pada tanggal 7 Juni 2012, dari http://www.mathgoodies.com/articles/problem_solving.ht $\mathrm{ml}$

Wardhani, Sri. (2004). Penilaian pembelajaran matematika berbasis kompetensi. Yogyakarta: PPPG Matematika Yogyakarta.

Wardhani, Sri \& Rumiati. (2011). Instrumen penilaian hasil belajar matematika smp: Belajar dari pisa dan timss. Yogyakarta: Pusat Pengembangan dan Pemberdayaan Pendidik dan Tenaga Kependidikan (PPPPTK) Matematika.

Wilson, J.W., Fernandez, M.L., \& Hadaway, N. (1993). Mathematical problem solving. Artikel. Diambil pada tanggal 8 November 2012, dari http://jwilson.coe.uga.edu/emt725/PSsyn /Pssyn.html 